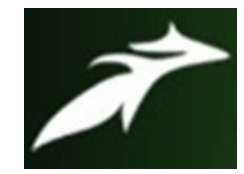

Prakash Kumar et al, International Journal of Advances in Agricultural Science \& Technology,

Vol.8 Issue.10, October-2021, pg. 48-59

ISSN: 2348-1358

Impact Factor: 6.057

NAAS Rating: 3.77

\title{
ATTITUDE OF BENEFICIARIES \& NON-BENEFICIARIES TOWARDS MAHATMA GANDHI NATIONAL RURAL EMPLOYMENT GUARANTEE ACT
}

\author{
Prakash Kumar* \\ M.Sc. Ag. (Agricultural Extension \& Communication)* \\ Prof. (Dr.) Ms. Jahanara** \\ Professor \& Head, Department of Agricultural Extension \& Communication, SHUATS Prayagraj Uttar Pradesh.** \\ Dr. Dipak Kumar Bose **** $^{*}$ \\ Associate Professor, Department of Agricultural Extension \& Communication, SHUATS Prayagraj Uttar Pradesh.*** \\ DOI: 10.47856/ijaast.2021.v08i10.006
}

\begin{abstract}
The Government of India created a historic act, by enacting the Mahatma Gandhi National Rural Employment Guarantee Act (MGNREGA), the largest employment generating programme in the world, ensuring the right to work in a country with a population of over one billion. This Act gives legal guarantee of at least one hundred days of wage employment in a financial year to a rural household, whose adult members volunteer to do unskilled and manual work. The present study was conducted in Dinara block of Rohtas district of Bihar. Ex post facto research design was followed for the analysis because the research is conducted after the occurrence of a particular incident. There are 61 villages in Dinara block, including the village of Dinara itself. Total number of 6 villages were selected through random sampling based on existence of MGNREGA Program. A total number of 60 beneficiaries and 60 non-beneficiaries of MGNREGA scheme were selected through random sampling for the present study. From the above analysis, it was concluded that 51.67 percent of the beneficiaries' respondents is having high level of Attitude, whereas in non-beneficiaries 56.67 percent of the respondents is having medium level of Attitude.
\end{abstract}

Keywords: MGNREGA, Employment, Attitude, Beneficiary etc. 


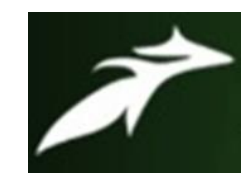

Prakash Kumar et al, International Journal of Advances in Agricultural Science \& Technology, Vol.8 Issue.10, October-2021, pg. 48-59

ISSN: 2348-1358

Impact Factor: 6.057

NAAS Rating: 3.77

\section{Introduction}

The Government of India created a historic act, by enacting the Mahatma Gandhi National Rural Employment Guarantee Act (MGNREGA), the largest employment generating programme in the world, ensuring the right to work in a country with a population of over one billion. The Government of India passed the NREGA 2005, (Central Act No. 42 of 2005). NREGA was renamed as Mahatma Gandhi National Rural Employment Guarantee Act (MGNREGA) on October $2^{\text {nd }}, 2009$. MGNREGA is the first ever law, in the world that guarantees wage employment at an unprecedented scale. This Act gives legal guarantee of at least one hundred days of wage employment in a financial year to a rural household, whose adult members volunteer to do unskilled and manual work. The Act is applicable in the Districts notified by the Government of India, the implementation of the Act calls for the formulation of Rural Employment Guarantee Scheme by the State Governments.

MGNREGA seeks the creation of durable and sustainable assets that are created by the community and also managed by it. For creation of such assets using the guaranteed employment, the act has codified works- water conservation and water harvesting, drought proofing (including afforestation and planting of trees), irrigationcanals (including micro and minor irrigation works), provision of irrigation facility to land owned by households of Scheduled castes and Scheduled Tribes (formerly lower castes and indigenous peoples) or to land of beneficiaries of land reforms and the Indira Awas Yojna (the house-building programme of the Government of India), renovation of traditional water bodies (including desilting of tanks), land development, flood control and protection works (including drainage in water-logged areas) and rural connectivity to provide all-weather access. Any other work which may be notified by the central government in consultation with the state government can also be considered. (Mehrotra, 2008). 


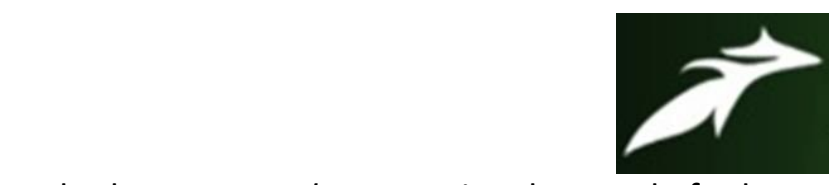

Prakash Kumar et al, International Journal of Advances in Agricultural Science \& Technology, Vol.8 Issue.10, October-2021, pg. 48-59

ISSN: 2348-1358

Impact Factor: 6.057

NAAS Rating: 3.77

\section{Research Methodology}

The present study was conducted in Dinara block of Rohtas district of Bihar. Ex post facto research design was followed for the analysis because the research is conducted after the occurrence of a particular incident. There are 61 villages in Dinara block, including the village of Dinara itself. Total number of 6 villages were selected through random sampling based on existence of MGNREGA Program. A total number of 60 beneficiaries and 60 non-beneficiaries of MGNREGA scheme were selected through random sampling for the present study. The study was based on primary \& secondary data. The data was collected from respondents by using the pre structured interview schedule. Data analysis is done through frequency and percentage distribution using statistical tools.

For calculating percentage, frequency was multiplied by 100 and divided by total number of Respondents.

$$
\mathrm{P}=\mathrm{X} / \mathrm{N} \times 100
$$

Where,

$\mathrm{P}=$ Percentage

$\mathrm{X}=$ Frequency of the Respondents

$\mathrm{N}=$ Total number of Respondents 


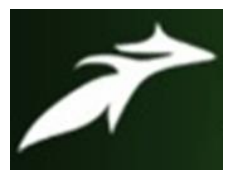

Prakash Kumar et al, International Journal of Advances in Agricultural Science \& Technology, Vol.8 Issue.10, October-2021, pg. 48-59

ISSN: 2348-1358

Impact Factor: 6.057

NAAS Rating: 3.77

\section{Results \& Discussion}

Table 1. Distribution according to the attitude of the beneficiaries:

\begin{tabular}{|c|c|c|c|c|}
\hline S. No. & Statements & $\begin{array}{l}\text { Agree } \\
\text { F(\%) }\end{array}$ & $\begin{array}{l}\text { Undecided } \\
\text { F(\%) }\end{array}$ & $\begin{array}{l}\text { Disagree } \\
\text { F }(\%)\end{array}$ \\
\hline 1. & $\begin{array}{l}\text { MGNREGA'S job guarantee scheme is } \\
\text { Boon to the rural people }\end{array}$ & 43(71.67) & $6(10)$ & $11(18.33)$ \\
\hline 2. & $\begin{array}{l}\text { Proper understanding of the scheme has } \\
\text { Been created among rural masses. }\end{array}$ & $41(68.33)$ & $9(15)$ & $10(16.67)$ \\
\hline 3. & $\begin{array}{l}\text { Sufficient work facilities have been } \\
\text { provided by MGNREGA. }\end{array}$ & $48(80)$ & $5(8.33)$ & $7(11.67)$ \\
\hline 4. & $\begin{array}{l}\text { MGNREGA has improved the lives of } \\
\text { Beneficiaries by generating income. }\end{array}$ & $45(75)$ & $11(18.33)$ & $4(6.67)$ \\
\hline 5. & $\begin{array}{l}\text { Unemployment allowance sustain family } \\
\text { When there is no work. }\end{array}$ & $5(8.33)$ & $15(25)$ & $40(66.67)$ \\
\hline 6. & $\begin{array}{l}\text { MGNREGA'S has been able to develop the } \\
\text { rural community and provide } \\
\text { employment. }\end{array}$ & $46(76.67)$ & $9(15)$ & $5(8.33)$ \\
\hline 7. & $\begin{array}{l}\text { Women are also encouraged to register } \\
\text { For employment. }\end{array}$ & $50(83.33)$ & $3(5)$ & $7(11.67)$ \\
\hline 8. & $\begin{array}{l}\text { The village council has accomplished the } \\
\text { Scheme successfully. }\end{array}$ & $42(70)$ & $10(16.67)$ & $8(13.33)$ \\
\hline 9. & Social auditing prevents mismanagement. & $39(65)$ & $12(20)$ & $9(15)$ \\
\hline
\end{tabular}




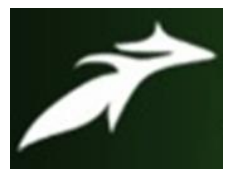

Prakash Kumar et al, International Journal of Advances in Agricultural Science \& Technology, Vol.8 Issue.10, October-2021, pg. 48-59

ISSN: 2348-1358

Impact Factor: 6.057

NAAS Rating: 3.77

\begin{tabular}{|l|l|c|c|c|}
\hline 10. & The community is greatly benefited by & $34(56.67)$ & $14(23.33)$ & $12(20)$ \\
& The asset creation. & & & \\
\hline 11. & The wage rate is standard and according & $38(63.33)$ & $17(28.83)$ & $5(8.34)$ \\
\hline 12. & MGNREGA scheme is good for & $3(5)$ & $42(70)$ & $15(25)$ \\
\hline 13. & Rural connectivity. & & & \\
\hline 14. & Flood control and Sanitation. & $0(0)$ & $45(75)$ & $15(25)$ \\
\hline 15. & Construction of School buildings. & $0(0)$ & $45(75)$ & $15(25)$ \\
\hline 16. & Construction of Government buildings. & $39(65)$ & $11(18.33)$ & $10(16.67)$ \\
\hline
\end{tabular}

\section{From this above Table-1 Major findings of beneficiaries are:}

- Majority of respondents (71.67\%) of Farmer's are agreed with their statement of MGNREGA'S job guarantee scheme is boon to the rural people.

- Majority of respondents $(68.33 \%)$ of the Farmers are agreed with their statement of Proper understanding of the scheme has been created among rural masses.

- Majority of respondents $(80 \%)$ of the respondents are agreed with their statement of sufficient work facilities have been provide by MGNREGA.

- Majority of respondents $(75 \%)$ of the respondents are agreed with their statement of MGNREGA has improved the lives of beneficiaries by generating income.

- Majority of respondents (66.67\%) of the respondents are disagree with their statement of Unemployment allowance sustain family when there is no work.

- Majority of respondents (76.67\%) of respondents are agreed with their statement of MGNREGA'S has been able to develop the rural community and provide employment. 


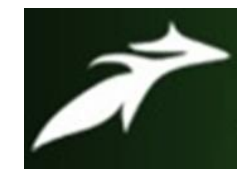

Prakash Kumar et al, International Journal of Advances in Agricultural Science \& Technology, Vol.8 Issue.10, October-2021, pg. 48-59

ISSN: 2348-1358

Impact Factor: 6.057

NAAS Rating: 3.77

- Majority of respondents (83.33\%) of the respondents are agreed with their statement of Women are also encouraged to register for employment.

- Majority of respondents (70\%) of the respondents are agreed with their statement of the village council has accomplished the scheme successfully.

- Majority of respondents $(65 \%)$ of the respondents are agreed with their statement of social auditing prevents mismanagement.

- Majority of respondents (56.67\%) of the respondents are agreed with their statement of the community is greatly benefited by the asset creation.

- Majority of respondents (63.33\%) of the respondents are agreed with their statement of the wage rate is standard and according to the community expectation.

- Majority of respondents $(70 \%)$ of the respondents are agreed with their statement of MGNREGA scheme is good for providing employment.

- Majority of respondents $(75 \%)$ of the respondents are undecided with their statement of rural connectivity.

- Majority of respondents $(75 \%)$ of the respondents are Undecided with their statement of Flood control and sanitization.

- Majority of respondents $(75 \%)$ of the respondents are Undecided with their statement of Construction of School building.

- Majority of respondents $(65 \%)$ of the respondents are agreed with their statement of Construction of Government buildings. 


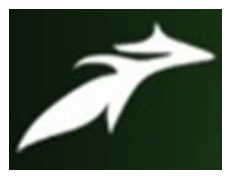

Prakash Kumar et al, International Journal of Advances in Agricultural Science \& Technology, Vol.8 Issue.10, October-2021, pg. 48-59

ISSN: 2348-1358

Impact Factor: 6.057

NAAS Rating: 3.77

Table 2. Distribution according to the Attitude of the Non-Beneficiaries regarding livelihood security

\begin{tabular}{|c|c|c|c|c|}
\hline S. No. & Statements & $\begin{array}{l}\text { Agree } \\
\text { F }(\%)\end{array}$ & $\begin{array}{c}\text { Undecided } \\
\mathbf{F}(\%)\end{array}$ & $\begin{array}{c}\text { Disagree } \\
\mathbf{F}(\%)\end{array}$ \\
\hline 1. & $\begin{array}{l}\text { MGNREGA'S job guarantee scheme is boon to } \\
\text { The rural people }\end{array}$ & $\begin{array}{c}57 \\
(95)\end{array}$ & $\begin{array}{l}3 \\
(5)\end{array}$ & $0(0)$ \\
\hline 2. & $\begin{array}{l}\text { Proper understanding of the scheme has been } \\
\text { Created among rural masses }\end{array}$ & $\begin{array}{c}55 \\
(91.66)\end{array}$ & $\begin{array}{c}5 \\
(8.33)\end{array}$ & $0(0)$ \\
\hline 3. & $\begin{array}{l}\text { Sufficient work facilities have been provided by } \\
\text { MGNREGA }\end{array}$ & $\begin{array}{c}25 \\
(41.66)\end{array}$ & $\begin{array}{c}35 \\
(58.33)\end{array}$ & $0(0)$ \\
\hline 4. & $\begin{array}{l}\text { MGNREGA has improved the lives of } \\
\text { Beneficiaries by generating income. }\end{array}$ & $\begin{array}{c}35 \\
(58.33)\end{array}$ & $\begin{array}{c}25 \\
(41.66)\end{array}$ & $\begin{array}{l}0 \\
(0)\end{array}$ \\
\hline 5. & $\begin{array}{l}\text { Unemployment allowance sustain family when } \\
\text { There is no work. }\end{array}$ & $\begin{array}{c}11 \\
(18.33)\end{array}$ & $\begin{array}{l}36 \\
(60)\end{array}$ & $\begin{array}{c}13 \\
(21.67)\end{array}$ \\
\hline 6. & $\begin{array}{l}\text { MGNREGA'S has been able to develop the rural } \\
\text { community and provide employment. }\end{array}$ & $\begin{array}{c}25 \\
(41.66)\end{array}$ & $\begin{array}{c}35 \\
(58.33)\end{array}$ & $\begin{array}{l}0 \\
(0)\end{array}$ \\
\hline 7. & $\begin{array}{l}\text { Women are also encouraged to register for } \\
\text { employment. }\end{array}$ & $\begin{array}{c}50 \\
(83.33)\end{array}$ & $\begin{array}{l}0 \\
(0)\end{array}$ & $\begin{array}{c}10 \\
(16.67)\end{array}$ \\
\hline 8. & $\begin{array}{l}\text { The village council has accomplished the } \\
\text { Scheme successfully. }\end{array}$ & $\begin{array}{c}15 \\
(25)\end{array}$ & $\begin{array}{c}40 \\
(67.67)\end{array}$ & $\begin{array}{c}5 \\
(8.33)\end{array}$ \\
\hline
\end{tabular}




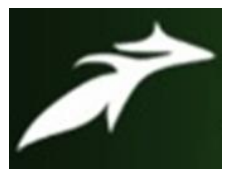

Prakash Kumar et al, International Journal of Advances in Agricultural Science \& Technology, Vol.8 Issue.10, October-2021, pg. 48-59

ISSN: 2348-1358

Impact Factor: 6.057

NAAS Rating: 3.77

\begin{tabular}{|l|l|c|c|c|}
\hline 9. & Social auditing prevents mismanagement. & $33(55)$ & $25(41.66)$ & $2(3.33)$ \\
\hline $\mathbf{1 0 .}$ & $\begin{array}{l}\text { The community is greatly benefited by the asset } \\
\text { creation. }\end{array}$ & $3(5)$ & $54(90)$ & $3(5)$ \\
\hline $\mathbf{1 1 .}$ & $\begin{array}{l}\text { The wage rate is standard and according to the } \\
\text { Community expectation. }\end{array}$ & 6 & 30 & 24 \\
\hline $\mathbf{1 2 .}$ & MGNREGA scheme is good for providing & 40 & 9 & 11 \\
& Employment & $(66.67)$ & $(15)$ & $(18.34)$ \\
\hline $\mathbf{1 3 .}$ & Rural connectivity & $0(0)$ & $40(66.67)$ & $20(33.33)$ \\
\hline $\mathbf{1 4 .}$ & Flood control and Sanitation & 10 & 30 & 20 \\
& & $(16.67)$ & $(50)$ & $(33.33)$ \\
\hline $\mathbf{1 5 .}$ & Construction of School buildings & $10(0)$ & $30(50)$ & $20(33.33)$ \\
\hline $\mathbf{1 6 .}$ & Construction of Government buildings & $24(40)$ & $35(58.33)$ & $1(1.67)$ \\
& & & & \\
\hline
\end{tabular}

From this above Table- 2 Major findings of non-beneficiaries are:

- Majority of respondents (95\%) of Farmer's are agreed with their statement of MGNREGA'S job guarantee scheme is boon to the rural people.

- Majority of respondents (91.6\%) of the Farmers are Agreed with their statement of Proper understanding of the scheme has been created among rural masses.

- Majority of respondents (56.66\%) of the Farmers are Undecided with their statement of sufficient work facilities have been provide by MGNREGA.

- Majority of respondents (58.33\%) of the Farmers are Agreed with their statement of MGNREGA has improved the lives of beneficiaries by generating income.

- Majority of respondents (60\%) of the Farmers are Undecided with their statement of Unemployment allowance sustain family when there is no work. 


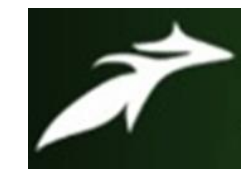

Prakash Kumar et al, International Journal of Advances in Agricultural Science \& Technology, Vol.8 Issue.10, October-2021, pg. 48-59

ISSN: 2348-1358

Impact Factor: 6.057

NAAS Rating: 3.77

- Majority of respondents (58.33\%) of respondents are Undecided with their statement of MGNREGA'S has been able to develop the rural community and provide employment.

- Majority of respondents (83.33\%) of the respondents are Agreed with their statement of Women are also encouraged to register for employment.

- Majority of respondents (67.67\%) of the respondents are Undecided with their statement of the village council has accomplished the scheme successfully.

- Majority of respondents (55\%) of the respondents are Agreed with their statement of Social auditing prevents mismanagement.

- Majority of respondents $(90 \%)$ of the respondents are Agreed with their statement of the community is greatly benefited by the asset creation.

- Majority of respondents $(50 \%)$ of the respondents are undecided with their statement of the wage rate is standard and according to the community expectation.

- Majority of respondents (66.67\%) of the respondents are agreed with their statement of MGNREGA scheme is good for providing employment.

- Majority of respondents $(66.67 \%)$ of the respondents are agreed with their statement of rural connectivity.

- Majority of respondents (50\%) of the respondents are Undecided with their statement of Flood control and sanitization.

- Majority of respondents (50\%) of the respondents are Undecided with their statement of Construction of School building.

- Majority of respondents $(58.33 \%)$ of the respondents are Undecided with their statement of Construction of Government buildings. 


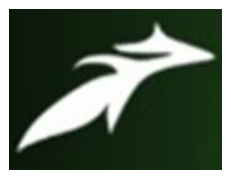

Prakash Kumar et al, International Journal of Advances in Agricultural Science \& Technology, Vol.8 Issue.10, October-2021, pg. 48-59

ISSN: 2348-1358

Impact Factor: 6.057

NAAS Rating: 3.77

Table 3. Overall Distribution according to the Attitude of the respondents:

\begin{tabular}{|l|c|c|c|c|c|}
\hline \multirow{2}{*}{ S. No. } & \multirow{2}{*}{ Category } & \multicolumn{2}{|c|}{ Beneficiaries } & \multicolumn{2}{c|}{ Non-Beneficiaries } \\
\cline { 3 - 6 } & Frequency & Percentage & Frequency & Percentage \\
\hline 1. & Low & 12 & 20 & 06 & 10.00 \\
\hline $\mathbf{2 .}$ & Medium & 17 & 28.33 & 34 & 56.67 \\
\hline 3. & High & 31 & 51.67 & 20 & 33.33 \\
\hline \multicolumn{2}{|}{ TOTAL } & $\mathbf{6 0}$ & $\mathbf{1 0 0}$ & $\mathbf{6 0}$ & $\mathbf{1 0 0}$ \\
\hline
\end{tabular}

Table 3. Shows that 20 percent of beneficiaries had very low level of Attitude, followed by 28.33 percent of the beneficiaries who had medium level of Attitude and 56.67 percent had High level of Attitude. Where as in non-beneficiaries 10 percent of the respondents had low level of Attitude followed by 56.67 percent had medium level of Attitude and 33.33 percent respondents had high level of Attitude. From the above analysis, it was concluded that 51.67 percent of the beneficiaries' respondents is having high level of Attitude, whereas in non-beneficiaries 56.67 percent of the respondents is having medium level of Attitude. 


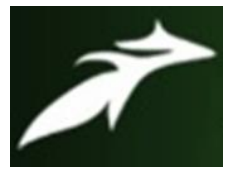

Prakash Kumar et al, International Journal of Advances in Agricultural Science \& Technology,

Vol.8 Issue.10, October-2021, pg. 48-59

ISSN: 2348-1358

Impact Factor: 6.057

NAAS Rating: 3.77

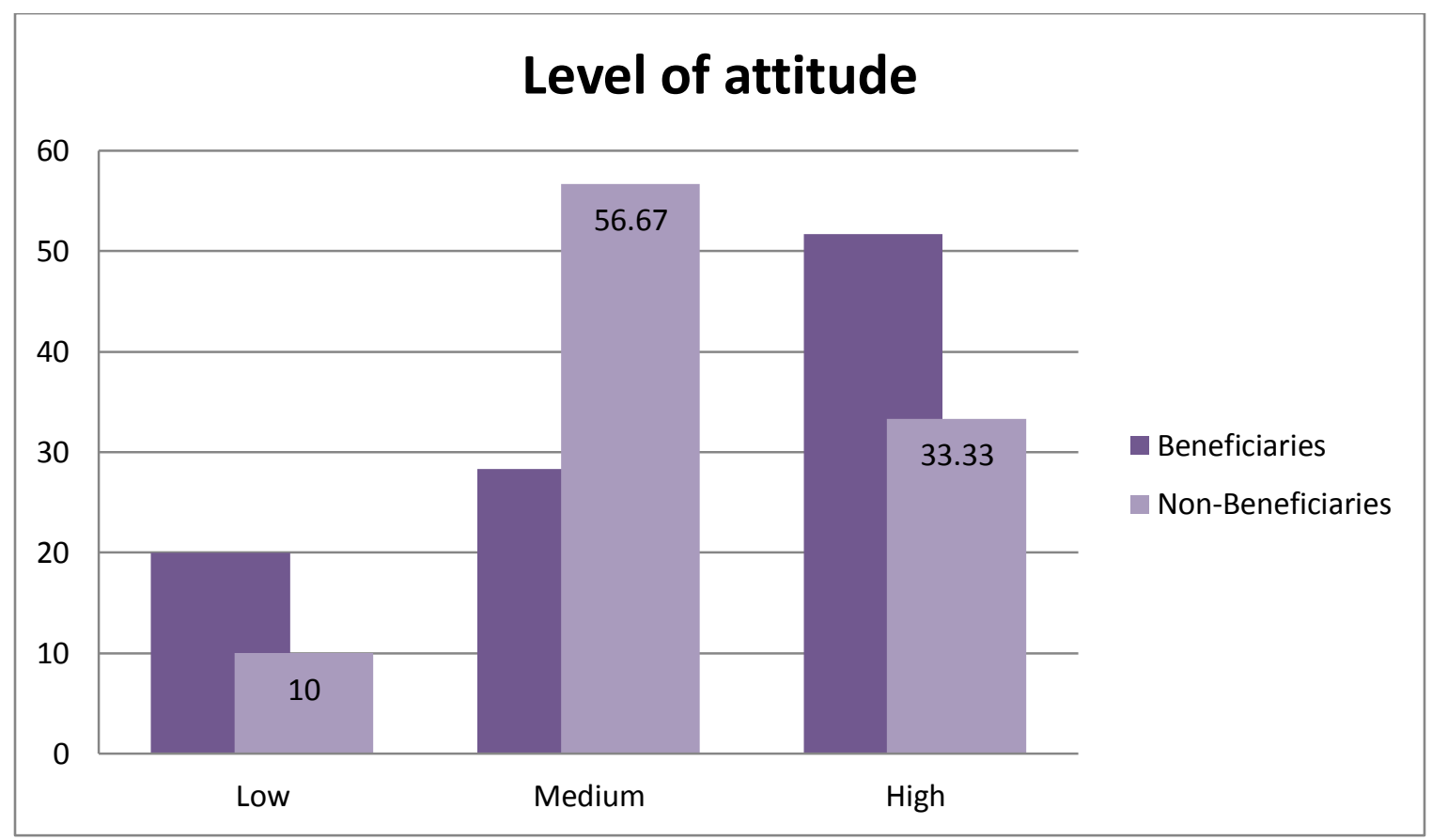

Figure1. Overall level of Attitude of the respondents

\section{Conclusion}

It is concluded that The Government of India created a historic act, by enacting the Mahatma Gandhi National Rural Employment Guarantee Act (MGNREGA), the largest employment generating programme in the world, ensuring the right to work in a country with a population of over one billion. This Act gives legal guarantee of at least one hundred days of wage employment in a financial year. It is concluded that 20 percent of beneficiaries had very low level of Attitude, followed by 28.33 percent of the beneficiaries who had medium level of Attitude and 56.67 percent had High level of Attitude. Where as in non-beneficiaries 10 percent of the respondents had low level of Attitude followed by 56.67 percent had medium level of Attitude and 33.33 percent respondents had high level of Attitude. From the above analysis, it was concluded that 51.67 percent of the beneficiaries' respondents is having high level of Attitude, whereas in non-beneficiaries 56.67 percent of the respondents is having medium level of Attitude. 


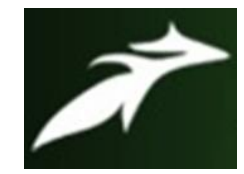

Prakash Kumar et al, International Journal of Advances in Agricultural Science \& Technology, Vol.8 Issue.10, October-2021, pg. 48-59

ISSN: 2348-1358

Impact Factor: 6.057

NAAS Rating: 3.77

\section{References}

- Adsul, G.B (2016) Socio-economic impact of National Horticulture Mission on its beneficiaries in Marathwada region. Ph.D. (Agri.) Thesis, Vasantarao Naik Marathwada Krishi Vidyapeeth, Parbhani (Maharashtra).

- Argade, S. A. (2010)., A Study on National Rural Employment Guarantee Scheme in Thanedistrict of Maharashtra. M.Sc. (Ag.) Thesis (Unpublished) Acharya N G Ranga AgricultureUniversity,Hyderabad (A.P).

- Badodiya, S.K., S. Tomar, M. M Patel and O. P. Daipuria (2012). Impact of Swarnjaynati Gram Swarozgar Yojana on poverty alleviation. Indian Res. J. Extn.Edu. 12(3) pp: 37-41.

- Dad bahu, A.S., and Gopi Krishna, T. (2013)., Sustainable Rural Livelihood for Small and Marginal Farmers through Employment Generation in Maharashtra. International Journal of Scientific Research. 2(5): 581-583.

- Garg N, Yadav H.R. (2010) "Community Development Programme-A Research Conducted on MGNREGA", International Journal of Business Economic and Management Research 2(10):121-128, 2011.

- Harish, B.G., (2010). An economic impact analysis of MGNREGA in Chikmagalaur district of Karnataka.M.Sc.(Agri) Thesis (Unpub.) University of Agricultural Sciences, Bangalore.

- Katanagoudar, S.B. (2011).Knowledge and Attitude of rural people about National Rural Employment Guarantee Scheme (NREGS) M.Sc.(Agri.) Thesis, Dharwad, Karnataka (India).

- Mehrotra, Santosh NREG Two Years on: Where Do We Go from Here? Economic and Political Weekly, 2008; 2:27-35. 